\title{
SOUTH AFRICA AND ZIMBABWE: \\ Democracy in the Littoral Zone
}

\author{
By \\ Peter Vale
}

Professor Peter Vale holds the Nelson Mandela Chair of Politics at Rhodes University, Grahamstown, South Africa. He is a Member of the South African

Academy of Science and a Fellow of the Royal Society of South Africa

Department of Political and International Studies, Rhodes University

PO Box 94 Grahamstown

Tel: +27(0)46 603 8354; Fax: +27(0)46 6224345

e-mail: p.vale@ru.ac.za

We are like travelers navigating an unknown terrain with the help of old maps, drawn at a different time and in response to different needs. While the terrain we are traveling on, the world society of states, has changed, our normative map has not.

Selya Benhabib

\begin{abstract}
Looking beyond routine explanations of the deteriorating situation in Zimbabwe, this paper examines mainstream understandings of Southern African politics and the language that produces them. It uses historical sociology to offer an alternative explanation of the development of the region and highlights the overlapping sources of authority that predated the state system. Drawing on the insightful poetry of Douglas Livingstone (and his own peregrinations in the region), the argument suggests that instead of an ontology based on state boundaries the region should be considered a 'littoral zone' in which authority and control move back and forth between different social bundles. Imaginative interpretations, rather than the 'weasel words' cult democracy, could help secure rights in Zimbabwe.
\end{abstract}

\section{INTRODUCTION}

Why are debates about the prospects for change in Zimbabwe threadbare? Insipid, uninspiring and terribly introspective, they turn and return to a mantra: insist on 'accountability', 'governance' and 'transparency' in the country; and insist, too, that South Africa, as it did before the Lancaster House Agreement 25 years ago, deliver Zimbabwe to the folds of modernity. 
When this option wilts, as it often does, the policy door swings towards 'liberal internationalism ${ }^{\prime 1}$ : this is the same option that propelled the United States (and its infamous 'Coalition of the Willing') to invade Iraq in order to free the country and liberate its people from Saddam Hussein's tyranny. So, and not occasionally, either, policy pundits (and others besides) suggests that the South African National Defence Force (SANDF) - or George W Bush - should invade Zimbabwe, remove Robert Mugabe and his cohort, and set the country's people free.

Although these options - democracy by formula and pressure, and armed invasion - make dramatic Op Ed pieces, they make little intellectual or political sense. One reason for this, and this explains the purpose of this paper, is that the two positions are distilled through the language and logic of interacting variables (Lapid 2001, p 3). As a result, it seems as if history and sociology - let alone the real business of politics, humanity - have no place in the relationship between South Africa and Zimbabwe. A little reflection, let alone a glance at a map, suggests that the two countries - a term used here only for illustrative purposes - have been intricately linked for more than a century.

The depressing outcome is that beyond the framing of state and nation - and the influence on both these of race - there is no imagination in the minds of those who are vocal on the topic. This explains why policy prescriptions seldom stray beyond the standard operating procedures that are at the core of contemporary diplomacy and which, as the dismal experience in Iraq shows, can be so dangerous.

Although largely unacknowledged, these prescriptions highlight an archaic understanding of the idea of policy - poliziwissenschaf: the science of regulating and maintaining social order (Bennett, Grossberg \& Morris 2005, pp 258-260). In its modern form, policy is worked and reworked within a series of protocols at the core of which is an array of key-words - the 'transparency', the 'accountability', the 'governance' - that we have already encountered. As this happens, understanding and imagination are stripped away from policy. The result? Policy is conceived within a series of technical outcomes, which retard rather than enhance the normative values which underpin democracy.

Explaining how this happens is easy. Notwithstanding (or because of) the success in overcoming apartheid, analysis and policy proposals aim at returning '... politics (in South Africa and the region) to the exercise of control and authority following the events of the hectic 1980s' (Vale 2005, p 10). So, policy-making in contemporary South Africa fosters the development of 'an administered society', to use a term from the critical theorist, Theodore Adorno.

Because of this, the unruly social world between South Africa and Zimbabwe (and within that country) is being willed to conform - to be administered. This is

This idea originated with Woodrow Wilson, America's 28th President, who emphasised US leadership through alliances and international organisations aimed at spreading democracy. Its most recent form has included the possibility of interfering in the domestic affairs of other countries to achieve this end. (From Judis 2005). 
not a value-free process however. The mantra we have already encountered 'accountability', 'governance' and 'transparency' - has been forged within the declaration of the 'end of ideology' first enunciated by the American sociologist, Daniel Bell (1961), and later reworked by the American-Japanese political theorist, Francis Fukuyama (1989, pp15-25).

The resulting policy diktat is rooted in neo-liberal ideology and, like all ideologies, is prescriptive: at its core is the idea that only free markets and ritualised politics can satisfy human instincts because history has ended. Zimbabwe's fate is that of other 'failed state[s]'; neo-patrimonial and corrupt. Zimbabwe's destiny is Africa's.

This pre-established vision of contemporary international relationships (and the formulae to counter them) is at the heart of the continued impasse in the relationship between South Africa and Zimbabwe.

How do we break this cycle of thought?

\section{HistORICAL SOCIOLOGY}

This question, and many others, can be answered by striking out in a different direction from that walked by the policy community. A promising approach begins with the recognition of the mutually constitutive (Lapid 2001, p 3) relationship between Zimbabwe and South Africa: appreciating this will position the relationship between the two countries in an entirely new relational and conceptual space which lies beyond the laws of interacting variables.

In any self-conscious reading, South Africa and Zimbabwe are continuously interacting social bundles - to use the anthropologists' term - not rigid, programmed physical entities. Understanding this form of the social is best located within the techniques of historical sociology, a perspective that lies apparently entirely outside the ken of those who pronounce on the relations between South Africa and Zimbabwe.

Let a few free-hand paragraphs, tapped from historical sociology, help to describe the social practice of mutually constituted forms in Southern Africa.

Without the foundation of the Union of South Africa in 1910, the formation of Southern Rhodesia - as the place called Zimbabwe was once known - would not have been possible. Indeed, as I have argued elsewhere, all other states in Southern African were modelled in (and on) South Africa (Vale 2003).

How Southern Rhodesia came to occupy a social form separated from South Africa is embedded in sociology. Very briefly, in the late1880s and into the 1890s the region comprised a number of social bundles which co-existed alongside each other. One of these was the British Empire, whose interest in Southern Africa north of the Cape Colony was awakened after the discovery first of diamonds and then of gold in the hinterland.

A parallel social form was sovereign organisation: this found periodic expression through the republican reflections of dissident people of European 
extraction who spoke a patois which was loosely derivative of Dutch - a language choice that, importantly, set them apart from English-speakers. The idea of national independence - along the lines of the United States of America - was a source of great inspiration and successive efforts to find a mechanism to express this goal. The result was the formation of the so-called 'Boer Republics', of which, for our immediate purposes, the Transvaal Republic was the most prominent.

In addition to these two sovereign-bound forms, a number of other social bundles were to be found. The first resulted from the redrawing by missionaries of cognitive maps. These have best been described by the anthropologists, Jean and John Comaroff (1991). A fourth form was less social, more economic: this was the co-option of territory within the imperial project and its translation into paper script, which was priced on the London Stock Exchange. The latter was invariably mediated - at great personal profit, of course - by great servants of Empire, like Cecil John Rhodes. These paragraphs suggest that far from neatly unfolding, the borders of the region moved backwards and forwards, driven by different impulses: at times, these were political; at times, economics was in the ascendancy; at times, even, social relations in Southern Africa were moved by spiritual impulses. The demarcation between what are all too readily called states, this account suggests, was not stable; indeed, the opposite is true, social interactions were fluid and mainly very, very violent.

\section{The Poet Speaks}

If historical sociology opens understandings beyond routine, state-bound interpretations, the lived experience opens new vistas, offering new understandings, and new appreciations of Southern Africa. To illustrate this point, I draw from scattered aspects of the life and work of the late Douglas Livingstone (1932-1996) ${ }^{2}$, the acclaimed Southern African poet.

A brief explanatory paragraph will be necessary for the regular readers of this journal. We read poetry for many reasons - and as with all art, poetry has a dynamic that engages the reader beyond the intentions of the artist. ${ }^{3}$ As I write these words, I am conscious that Douglas Livingstone despised politics. If, however, the definition of politics is broadened to embrace issues of race, gender, class, and, pointedly, the environment, then, plainly, Douglas Livingstone rejoiced as much in politics as he did in the idea of Southern Africa.

Douglas Livingstone's life and work embraced, both autobiographically and intellectually, a wide and fluid experience. Using both of these as a point of entry, enables us to appreciate that the building of Southern African involved a continual

2 The information on Douglas Livingstone is drawn from Hacksley \& Maclennan 2004. Some of the ideas in this paper come from Vale 2004.

3 My Rhodes colleague, Corinne Knowles, helped me understand this issue. 
repositioning of social relations: an ongoing negotiation, if you like, between social bundles.

Livingstone's early years in Malaya (where he was born), Australia (where he lived briefly as a child), and South Africa's Natal province (where he was schooled), confirm that he was socialised into a particular understanding of how the world '[hangs] together in the international sense' (Ruggie, quoted by Lapid in Mathias, Jacobsen \& Lapid 2001, p 1). However random, even, perhaps, dysfunctional, this pattern seems, Livingstone's nomadic childhood made sense in the 1930s and 1940s even though the British Empire, into which he was born, was living on a political overdraft. We should not be surprised that Livingstone's life and his work mirror the same understanding of how the 'world hangs together'. The unfolding of Livingstone's post-school career, which was marked by perambulations and peregrinations in Southern Africa, completed an experience of the international that is familiar to many, this author included, who are drawn from the same late-imperial cohort. That Livingstone travelled from Natal to a professional position in what was then Southern Rhodesia is not surprising; that this sojourn was followed by posts in Lusaka and, later, Broken Hill, both of these in a place we now call Zambia, not untoward.

Because today it is believed that Southern African states make the region, and that mediation between these 'interacting variables' is only possible within diplomatic ritual, we have no memory of a time when the frontiers between the 'states' of Southern Africa were entirely porous. That they were porous, however, did not escape ambitious politicians: so, for example, in a speech in April 1940, South Africa's then Prime Minister, Jan C Smuts, made an appeal for the country's pan-African destiny, returning to a theme that he had first spoken of 45 years earlier (Smuts 1942).

The currency that Livingstone would have had in his pocket when he set off from Durban for Salisbury (now Harare) in 1951 was the Pound Sterling - then the only acceptable tender between Cape Town and Nairobi - Angola and Mozambique, excluded by their different colonial status, of course. And it is sobering to recall that Southern Rhodesia, where Livingstone took his initial diploma in medical technology, the first step towards a PhD in Biology Science (obtained in 1989), was then a state a little over thirty years old!

The taming of social relations through the mediation of official certification (and the issuing of separate currency) was integral to the project of reordering (read: bringing into line) social relations in Southern Africa. But more ambitious forms of modernity were required to tame nature. And, in Southern Africa, no engineering project was more ambitious than the building of the Kariba Dam, where Livingstone worked periodically as a diver in 1957. In his first collection of verse, The Skull in the $\mathrm{Mud}$, a poem of the same name, that describes a sub-maritime encounter, is to be found. Here follow a few stanzas:

Braced by aqualung belts, and hot help-handed by two small black boys, 
the dam-site twisting, stamped with noise...

he sank suddenly weightless down..

He nudged the bottom, tripped the light, saw not two hands' breadths from his nose a yellow skull, dull, tenebrose jawless in muds of liquid night ...

Vomited up from swarthy rocks lining the river's ancient bed, it perched, sardonic, gently dead, tossed up by new construction shocks.

The pair exchanged a filmy stare...

Politely he backed, broke the tie The skull's wink flicked swift as a knife:

A small minnow intent on life Shot twinkling from one hollow eye.

Hacksley \& Maclennan 2004, pp 5-6

Like the 'progress' offered by redirecting great colonial rivers, modernity's promise was to harden the national borders between Southern Africa's states.

In contrast, Livingstone understood that 'the international world hung together' differently; there were no borders, only endlessly shifting social forms. They were - as he may well have expressed it - a littoral zone - 'that mysterious border that shifts restlessly between land and sea' (see Brown 2002, pp 94-116; Morphet 1997, pp 205-211).

This zone was arbitrary, capricious, vacillating, notwithstanding the ambitious empire- and state-building projects pursued by successive colonial governments and ambitious European settlers.

Livingstone certainly recognised the irony of all this. In the poem Letters from Southern Rhodesia, first published in 1956, he captures the lure and lore of statemaking in that eponymous country with this cunning double-header:

cecil's been painted green again while tall

calabashes virtuously scrape the sky

of sunlight and giant silver birds of night

plenty of room for the new settlers if

they do remember to bring their own tents

Hacksley \& Maclennan, p 321 
It should be remembered that this was a time when white Southern Africans Afrikaners included $^{4}$ - were deeply linked into the sub-continent - especially northwards towards two places then called Rhodesia, and separated only by the geographical descriptors, Northern and Southern.

However, and this is certainly more important for the present situation, their black regional counterparts were also possessed - is prepossessed too strong a word? - by a pan-Southern Africanism. In the early-1990s an impressive list of studies was to show that the region was constituted by migrant labour patterns that had, at that point, endured for almost a century (see Maloka 1997, pp 213-224). Let one iconic name stand for millions of the region's people who helped to make South Africa and the region one and indivisible: Clements Kadalie, born in the then Nyasaland in 1896, who, in 1919, formed the first black-led union - the Industrial and Commercial Union (ICU), with its headquarters in Cape Town.

Another poet, Ingrid de Kok, captured these 'colonial circuits of care and demand' in a poem, 'William Kamanga', which lovingly describes a life fashioned by a Southern African experience from below. It includes this stanza:

And on Sunday afternoon, when visitors

Who knew the dogs by name

Sat outside in suits and ties,

Talking softly about Banda

And the cost of transport home.

De Kok 2002, pp 50-51

It is important to note, as we move between Livingstone's late-colonial world and Kamanga's post-colonial world, that the former opens himself to the possibility that, while 'At Home' in Southern Africa, his own belonging is temporary.

The sky is blue, the row of crops stand neat, the river's down, old herons hunt the sludge, the land will last, the people come and go.

Hacksley \& Maclennan 2004, p 3

The independence movement of the early 1960s, with its call for self-determination and nation-building, confirmed the sanctity of national borders - freezing them, if you like. As it did so, the theory and practice of movement and social freedom changed Southern Africa's social form away from the porous borders which had made Livingstone's wanderings across the region possible.

4 Much work remains to be done in relation to the issue of Afrikaners in the sub-continent. This will have to focus on the shibboleth that there was an outward spillage from South Africa of so-called 'Trekkers'. For the latest insertion of this idea into the canon see Muller 2005, p 167. 
This modernist movement was sealed in 1961 by Hendrik Verwoerd's South African Republic, with its increasing preoccupation with borders and security (see Stultz 1969, pp 3-20). This launched, on the other side of the border, another political mantra - one that would run for close on 40 years - 'end colonialism, end minorityrule, end apartheid'.

\section{A New Ontology}

After this the region's 'littoral zone' was increasingly lost in an analytical sense, too. The rise of positivist social science sought to set aside 'primitive understandings' of social relations in Southern Africa. New interpretations argued that these could only be understood within five assumptions around power: international politics is about states; states seek (military) power because nothing else can guarantee their security; relations between states are guided by national interests; it is possible - no, imperative - to distinguish between the political and the economic; and because the world is driven by calculations of power, states must prepare for war. ${ }^{5}$

It was only a short move from these ideas to the understanding that Southern African states should ideally operate within a regional state 'system'. This notion was introduced into the study of politics in the late 1930s (McLean \& McMillan 2003) and perfected, by drawing analogies from biology, in the late 1950s: its functionalist thread suggested that political systems, like biological systems, could be self-regulating and homeostatic (see Dogan 1998, p 107). Important, too, was the identification of a 'system' - ideally, its characteristics included distinguishing its boundaries, recognising its purpose, and defining the level of abstraction to which the system is to be treated (Bullock \& Trombley 1999, p 855).

The idea migrated into the political discourse of Southern Africa in the late 1960s with the work of the American political scientist, Larry Bowman (1968, pp 231-261). Four years later, the idea was imprinted in the regional canon by the success of a book (Potholm \& Dale 1972) which first described the region within the discursive framing of the 'science' of Politics. As the idea settled, both the region's history and sociology were ignored: what mattered was the need to force the region into 'state containers' - to use Peter Taylor's term (1994, pp 151-162). These were fashioned in the language of interacting variables - a language that could be of use to analysts and practitioners alike.

This artificial form for the region - state-based, state-centred, state-dominant - reinforced the kind of politics that Douglas Livingstone despised. It is not surprising, then, that Livingstone's satire was sharp, spiky, and even sassy. Read this, from a series of poems under the collective title: Where's The Political Commitment To Your Work, Mr Livingstone?:

5 These ideas have been distilled from Nossal 1998, p 15. 
If you work in a snake-park

Wear long gloves and goggles

And sensible boots, thick in the heel;

Stay out of the pits after dark.

Tramping the veld demands caution,

But there's less of a chance of acquiring

A concentration of venom

From trap-wires of rusting steel.

Hacksley \& Maclennan 2004, p 530

My purpose in introducing Livingstone and his work is not to romanticise the hope and, indeed, virtue, that post-World War II Southern Africa held out for whites of a particular generation, including Livingstone's and my own. Assessments of this period will be the work of a cohort born in the 1980s. In important ways, their work has already begun: the deepening interest by scholars (both of history and politics) in Southern Rhodesia may, perhaps, intensify the salience of the impact of the decisions of late-colonialism on individual lives (see Wylie 2005; Vale 2005). Let us be clear about this particular development: There is no re-creating the Home Counties in Southern Africa, as white Rhodesians tried to do: there is also no point in trying to recover the colonial project in the region by using Livingstone as point of entry.

However, another far more promising development, tapped from Livingstone's work, is important for the region's future.

Recent debates have moved away from the significance of borders and boundaries towards the exploration of new social bundles for a Southern Africa which faces multiple new challenges. This search tries to understand new terrains of regional intercourse, like cross-border trading, or music, or poetry and other art forms - or, to put it more succinctly, the practical, spiritual and cultural exchanges of trade, music and art.

This new (and not-so-new) searching lies beyond colonialism, beyond nationalism, beyond apartheid: it aims to construct (or remake) a borderless community in Southern Africa. This is a return to Livingstone's 'Littoral Zone' while, at the same time finding a way 'to heal the earth, this wonderful planet that we live on' - to use Livingstone's compelling words (Chapman 1985, p 112).

Like all ideas, this new thinking on Southern Africa begins with critical questions. Why it is that water, which gives life to Southern Africa's people, divides the region? Why are symbols of the region's modernisation - industries, urban sprawls, and developed mine-heads - located far from supplies of water? Why were elaborate transfer schemes - like the Kariba Dam - built? Why has water been turned into a price mechanism?

These and other questions protest the intimate relationship between international capital, local industry, and state-building by pointing out that the region's current managerial and technical form favours the rich and the powerful! 
Much the most exciting and interesting of these questions have come from the Canadian scholar of the region, resident of Botswana and himself a prize-winning poet, Larry Swatuk (See, for example, Swatuk 2002, pp 507-30; Swatuk 2003, pp 897-906; Swatuk 2004, pp 872-880); most of it, unfortunately, appeared after Douglas Livingstone's untimely death in 1996.

We cannot, of course, know what Livingstone would have made of this unexpected turn in the region's unfolding story. But a rudimentary (and admittedly thin) interpretation of Livingstone's work suggests that ecological politics was close to his heart. Listen to his plea for the planet in the recently published poem called 'A Death of Green'.

Part of it all hands unclean

As the rest, I wondered if the matches,

Newssheets, planks and plastics,

pitprops, sleepers, telephone-

uprights for country party-lines

were worth half a hillside

of twenty-five summers

nodding peacefully in the sun.

Hacksley \& Maclennan, p 445

The South African writer Jack Cope once said, 'Poets are not buried with their bodies, but remain to awake the living' (cited in De Bruin 2004, pp 26-30). This idea might assist us as we strike out in a new direction that reconstructs the region by placing ecology, not states, at the centre of our analytical focus. This, however, is not the central concern of this paper and attention must now return to the complexity of the relationship between South Africa and Zimbabwe.

\section{Citizenship}

It has become commonplace to suggest that sovereign independence - in Africa and elsewhere, too - has not delivered what it once promised. The question which must be answered is Lenin's: 'What is to be done?'.

As argued in the opening lines of this paper, the coercion and invasion have not proved to be options sufficient to assist Zimbabwe's embattled people. Therefore, rather than the rote and routine responses of the policy community, the standardoperating-procedures that are at the core of contemporary politics, attention must turn to the power of imagination - an imagination that begins with theory and ends in practice.

Livingstone's metaphor offers the space to explore new forms of politics. These will not be state-based; they will not rest on the paradox of sovereignty; they will not draw from the canon of states; they will not reply in the invented tradition of Westphalia. Rather, they will seek to fashion cosmopolitan identities which are 
located either above or below the existing states and the 'system' they pursue. These politics will be versions of the pan-Southern Africanist life that was lived by both Douglas Livingstone and by William Kamanga, who, like the region's growing number of refugees, have a different understanding of how, internationally, the world hangs together.

These 'in-between' groupings - for want of a better term - challenge political imagination because they require us to search for ways to measure the social world beyond state-based maps. They require us to imagine and describe the region as it was before the rational ordering offered by nationality and territory.

In a provocative recent piece Sylvia Benhabib (2005, pp 673-677) reminds us that some writers have grappled with a political dilemma parallel to the one Southern Africa now faces. The philosopher John Rawls's idea of the 'law of people', for example, and the idea of a 'cosmopolitan citizenship centred on a new law of nations' suggested by Jürgen Habermas (Benhabib 2005, p 674). These and other theorists recognise that the state faces immense challenges in an age in which ideas like globalisation have taken hold and in which the migration of people across borders grows exponentially.

So, ideas on belonging and identity which are rooted in the geometry of sovereignty are no longer sufficient. This raises this question: 'What kind of shared citizenship is ... possible in a world made up of separate nation-states? (Bybee 2005, p 503).'

Even though, ironically, the wars to end colonialism, minority rule and apartheid have ended 'state containers' in Southern Africa cannot hold their people. As the hoary issues of Zimbabwe (and Swaziland and others besides) haunt the region's politics, the policy conversation can only turn to reinforcing the very states that have failed to hold Southern Africa's social bundles together.

Where, then, are the ideas about transnational citizenship for the region? Where is the thinking that will guarantee the rights of the people's people wherever and whenever they are threatened? Where is the inspiration that calls for Southern Africa as a littoral zone? Where is the vision that looks beyond states and constructs a region of people?

\section{Weasel Words}

Those reading a journal devoted to the promotion of credible elections in Southern Africa might wonder why this paper is entirely registered outside of the standardised grammar that has celebrated the cult of democracy that has flourished since the end of the Cold War. My purpose has been to highlight a paradox tapped from Heidegger: language, far from being the servant of man, is all too often his master.

The political mantra 'governance', 'transparency' and 'accountability' does not help to explain the world; indeed, this is not its purpose. The purpose of these words is to exercise control over the social world by speaking to the high ideals of 
democracy. They therefore aim at manipulation and control rather than at fostering the goals of emancipation within which the idea of democracy - and liberation in the region - was originally conceived.

They are 'weasel words', to use a term once used by Theodore Roosevelt ${ }^{6}$, and the technically-based social practices they encourage are derivative of the parochialism and consumption which has marked the project of modernity in the region and elsewhere.

They do not assist us to understand Zimbabwe, and will not assist in resolving the complex relationship between South Africa and Zimbabwe. This is because Zimbabwe is a polity mired in the language and ritual of African nationalism; indeed, the country is a political artefact of early decolonisation. These politics will not be dissolved through the coded language and cargo cult of applied democracy (Vale 2005, p 14).

This says something about the nature of intellectual work. Applied academic disciplines are notoriously unselfconscious and one-dimensional, which makes them easily beholden to special interests. Not surprisingly, then, policy, which frames action rather than describes it, is a notoriously philistine experience.

The gap between bringing Zimbabwe to order and the fate of that country's people has widened, not narrowed, in the face of increasingly shrill policy proposals. This is because the cognitive maps that are used by self-styled policy experts to understand the dynamics of the region have no place for the littoral zones. To rely on these authorities and their charts to carve a way forward is, tragically, to wish for more of the same.

6 The exact quote is both interesting and important:

One of our defects as a nation is a tendency to use what have been called 'weasel words'. When a weasel sucks eggs the meat is sucked out of the egg. If you use a 'weasel word' after another there is nothing left of the other. 


\section{- REFERENCES -}

Bell, D. 1961. The End of Ideology: On the Exhaustion of Political Ideas in the Fifties. New York: Collier.

Benhabib, S. 2005. 'Borders, Boundaries and Citizenship'. PS: Political Science and Politics, XXXVII(4).

Bennett, T, L Grossberg \& M Morris (eds). 2005. New Keywords. A Revised Vocabulary of Culture and Society. Oxford: Blackwell.

Bowman, L W. 1968. 'The Subordinate State System of Southern Africa'. International Studies Quarterly 12(3).

Brown, D. 2002. 'Environment and Identity: Douglas Livingstone's A Littoral Zone'. Critical Arts 16(2).

Bullock, A \& S Trombley. 1999. The New Fontana Dictionary of Modern Thought. London: HarperCollins.

Bybee, K J (ed). 2005. 'Citizenship at Home and Abroad'. Forum in International Studies Review 7(3).

Chapman, M. 1985. ‘Douglas Livingstone: Poet Scientist'. Leadership 4(3).

Comaroff, J and J Comaroff. 1991. Of Revelation and Revolution. Christianity, Colonialism and Consciousness in South Africa (Vol One). Chicago: The University of Chicago Press.

De Bruin, P. 2004. 'Rest in Peace'. MEG Leisure, September.

De Kok, I. 2002. 'William Kamanga'. In I de Kok. Terrestrial Things. Cape Town: Kwela/Snailpress.

Dogan, M. 1998. 'Political Science and Other Social Sciences'. In R E Goodin \& H-D Klingman (eds). A New Handbook of Political Science. New York: Oxford University Press.

Fukuyama, F. 1989. 'The End of History? After the Battle of Jena'. The National Interest 18.

Hacksley, M and D Maclennan (eds). 2004. A Ruthless Fidelity. The Collected Poems of Douglas Livingstone. Johannesburg and Cape Town: AD Donker.

Judis, J B. 2005. 'The Return of Isolationism'. The New Republic Online post date: 23 November.

Lapid, Y. 2001. ‘Identities, Borders, Orders: Nudging International Relations Theory in a New Direction'. In A Mathias, D Jacobsen \& Y Lapid (eds). Identities, Borders, Orders: Rethinking International Relations Theory. University of Minnesota Press (Borderlines 18).

Maloka, T.1997. 'Mines and Labour Migrants in Southern Africa'. Journal of Historical Sociology 10(2).

McLean, I \& A McMillan (eds). 2003. The Concise Oxford Dictionary of Politics. Oxford University Press, 2003. Oxford Reference Online. Oxford University Press, Rhodes University Library25 November 2005

<http:/ / www.oxfordreference.com/views /

ENTRY.html?subview=Main\&entry=t86.e1363> 
Morphet, T. 1997. 'Littorally: a note on Douglas Livingstone'. Pretexts: studies in writing and culture 6(2).

Muller, C F J. 2005. 'Southern Africa: Mozambique, Belgian Congo and Angola'. In T Wheeler. History of the Department of Foreign Affairs 1927-1993. Braamfontein: South African Institute of International Affairs.

Nossal, K R. 1998. The Patterns of World Politics. London: Prentice-Hall.

Potholm, C P \& R Dale (eds). 1972. Southern Africa in Perspective: Essays in Regional Politics. New York: The Free Press.

Scarpetta, G. 2005. 'The Fall of the Curtain.A permanent rebel'. Le Monde Diplomatique, November.

Smuts, J C. 1942. 'Greater South Africa'. In Plans for a Better World. London: Hodder and Stoughton.

Stultz, N M. 1969. 'The Politics of Security: South Africa under Verwoerd, 1961-6'. The Journal of Modern African Studies 7(1).

Swatuk, L A. 2002. 'The New Water Architecture in Southern Africa: reflections on current trends in light of Rio +10 '. International Affairs 78(3).

-2003. 'State Interests and Multilateral Cooperation: Thinking Strategically About Achieving "Wise Use" of the Okavango Delta System'. Physics and Chemistry of the Earth 28(20-27).

2004. 'Political challenges to implementation of IWRM in Southern Africa'. Physics and Chemistry of the Earth 30(11-16).

Taylor, P J. 1994. 'The State as Container: Territoriality in the modern world system'. Progress in Human Geography 18(2).

Vale, P. 2003. Security and Politics in South Africa: The Regional Dimension. Boulder, Colorado and London: Lynne Rienner Publishers.

2004. 'Notes Prepared for the Book Launch of Malcolm Hacksley and Don McLennan (eds). A Ruthless Fidelity. The Collected Poems of Douglas Livingstone. National English Literary Museum (NELM) Grahamstown, Friday, 8 October $2004^{\prime}$.

-2005. No Bells and Whistles: What is politics today? Inaugural Lecture. Delivered on 25 May 2005. Grahamstown: Rhodes University. 2005. 'A moment that shaped decades'. Business Day, 11 November.

Wylie, D. 2005. 'Remarks made at the opening of an exhibition of art entitled “Debris” by Roxanne Dardagan'. Grahamstown, 26 June. 